\title{
WHATSAPP BOT "KITA SEHATI (KABAR, INFORMASI, DAN BERITA SEPUTAR KESEHATAN DAN GIZI)": MEDIA PENYEBARAN INFORMASI GIZI DAN KESEHATAN BERBASIS TEKNOLOGI 4.0
}

\author{
Rosyanne Kushargina ${ }^{1}{ }^{*}$, Anisa Nurul Syafitri ${ }^{1}$, Ardelia Evani ${ }^{1}$ dan Sri Laksmi Fitriyani ${ }^{1}$ \\ ${ }^{1}$ Program Studi Sarjana Gizi, Fakultas Kedokteran dan Kesehatan, Universitas Muhammadiyah Jakarta \\ Jl. Cempaka Putih Tengah 46 No 27, Jakarta Pusat 10510, Indonesia \\ Telp./Fax. (021)7492135 \\ *Email : rosyanne.kushargina@umj.ac.id
}

\begin{tabular}{l}
\hline Article Info \\
\hline Article history: \\
Received July $15^{\text {th }}, 2021$ \\
Revised August $20^{\text {th }}, 2021$ \\
Accepte September $25^{\text {th }}, 2021$
\end{tabular}

\section{Kata Kunci :}

Informasi Gizi dan Kesehatan; Teknologi 4.0; WhatsApp Bot

\begin{abstract}
Background : Internet use in Indonesia was increased, especially in the current situation of the Covid-19 pandemic. WhatsApp is one of the social media that highest used in Indonesia. Information can be spread quickly and widely through WhatsApp.
\end{abstract}

Objective : This research aimed to develop the WhatsApp Bot application namely WhatsApp Bot Kita SeHatI as Media for dissemination of nutrition and health information.

Methods : WhatsApp Bot Kita SeHatI was designed in three steps. The First step was collecting data information, that highest searching in public regarding health and nutrition using an electronic questionnaire. This data used for information content that was entered into the WhatsApp Bot Kita SeHatI. The second step was the development of the WhatsApp Bot. The third step was testing. Subjek filled evaluation form through an electronic questionnaire after accessed the WhatsApp Bot to evaluate the assessment and benefits of the WhatsApp Bot using the Likert scale. The data obtained were analyzed descriptively based on the percentage of subjek's assessments.

Result : Information related to food for immunity was the highest searching by subjek (37,40\%). All features of WhatsApp Bot were working. WhatsApp Bot Kita SeHatI is useful $(93,9 \%)$ and effective (91.8\%) to find information about health and nutrition, and the overall assessment for WhatsApp Bot Kita SeHatI is good (89,8\%).

Conclusion : WhatsApp Bot Kita SeHatI was developed as Media for the dissemination of nutrition and health information based on technology 4.0. WhatsApp Bot Kita SeHatI can be accessed at https://bit.ly/KitaSeHatIBot or via WhatsApp number +6285156531135. WhatsApp Bot Kita SeHatI which was developed was working, useful, effective, and good.

\footnotetext{
ABSTRAK

Pendahuluan : Penggunaan internet di Indonesia meningkat, terlebih dalam situasi pandemi Covid-19 yang saat ini masih berlangsung. WhatsApp menjadi salah satu media sosial yang banyak digunakan oleh masyarakat Indonesia. Informasi dapat disebarkan dengan cepat dan jangkauan yang luas melalui WhatsApp.
}

Tujuan : Tujuan dari penelitian ini adalah untuk mengembangkan 
aplikasi WhatsApp Bot Kita SeHatI sebagai media penyebaran kabar, informasi, dan berita seputar kesehatan dan gizi.

Metode : Perancangan WhatsApp Bot dilakukan dalam tiga tahap. Tahap pertama dilakukan untuk mengumpulkan data tentang informasi apa saja yang banyak dicari oleh masyarakat terkait kesehatan dan gizi menggunakan kuesioner elektronik. Data tersebut menjadi dasar informasi yang dimasukkan ke dalam WhatsApp Bot Kita SeHatI. Tahap kedua adalah dilakukan pengembangan WhatsApp Bot. Tahap ketiga adalah uji coba. subjek mengisi formulir evaluasi melalui kuesioner elektronik setelah mengakses WhatsApp Bot untuk evaluasi penilaian dan kemanfaatan WhatsApp Bot dalam bentuk skala likert. Data yang diperoleh dianalisis secara deskriptif berdasarkan persentase penilaian subjek.

Hasil : Informasi terkait makanan untuk imunitas tubuh paling banyak dicari oleh subjek (37,40\%). Semua fitur WhatsApp Bot berfungsi dengan baik. WhatsApp Bot Kita SeHatI dinilai bermanfaat $(93,9 \%)$ dan efektif $(91,8 \%)$ untuk mencari informasi seputar kesehatan dan gizi serta penilaian secara keseluruhan sudah baik $(89,8 \%)$.

Kesimpulan : WhatsApp Bot Kita SeHatI dikembangkan untuk penyebaran informasi kesehatan dan gizi berbasis teknologi, mendukung perkembangan pada era teknologi 4.0. WhatsApp Bot Kita SeHatI dapat diakses pada https://bit.ly/KitaSeHatIBot atau melalui nomor WhatsApp 085156531135. WhatsApp Bot Kita SeHatI yang dikembangkan berfungsi dengan baik, dinilai bermanfaat, efektif, dan baik secara keseluruhan.

\section{PENDAHULUAN}

Dunia sudah memasuki Era industri 4.0. Era ini telah dianggap sebagai tahap industri baru di mana teknologi digital banyak digunakan (Frank, Dalenogare and Ayala, 2019). Hal yang paling mencolok pada era ini adalah penggunaan internet yang meningkat pesat. Ini dikenal juga dengan istilah Internet of things (IoT) (Bongomin et al., 2020). Telah terjadi pergeseran paradigma baru pada era industri 4.0, di mana sains dikembangkan berbasis teknologi digital.

Salah satu bukti telah berkembangnya teknologi informasi dan komunikasi saat ini ditandai dengan semakin populernya penggunaan media social. Media sosial memudahkan masyarakat untuk mencari informasi, berkomunikasi dan saling bertukar pendapat. Berbagai macam aplikasi media sosial digunakan masyarakat luas seperti WhatsApp, Instagram, Twitter, Facebook, Line, dan sosia media lainnya (Trisnani, 2017). Tentunya penggunaan media sosial sejalan dengan kapasitas jaringan internet yang memadai di Indonesia (Azmi, 2015).

Penggunaan internet di Indonesia meningkat, terlebih dalam situasi pandemi Covid-19 yang saat ini masih berlangsung. Kegiatan belajar dan bekerja dilakukan dari rumah serta adanya pembatasan mobilitas menjadi penyebab meningkatnya penggunaan internet (Zulfitria, Ansharullah and Fadhillah, 2020). Berdasarkan data dari survei Hootsuite pada Januari 2020, WhatsApp menjadi salah satu media sosial yang banyak digunakan oleh masyarakat Indonesia. WhatsApp digunakan oleh $84 \%$ masyarakat Indonesia yang menggunakan internet atau mencapai 175,4 juta orang (We Are Social \& Hootsuite, 2020).

WhatsApp sendiri memiliki berbagai fitur selain pesan teks seperti, video call, panggilan suara, mengirim berbagai macam file seperti gambar, video, dokumen, dan dapat membuat grup chat yang memudahkan untuk berbagi informasi kepada banyak orang. Sehingga WhatsApp tidak hanya menjadi media komunikasi semata, tetapi dapat menjadi media diseminasi informasi (Rahardjo et al., 2020).

Informasi dapat disebarkan dengan cepat dan jangkauan yang luas melalui WhatsApp. Saat pandemi Covid- 
19 masyarakat membutuhkan informasi terutama tentang kesehatan untuk terhindar dari paparan Covid-19 (Yulianti et al., 2020). Informasi tentang gizi, khususnya tentang makanan dan minuman yang dapat meningkatkan imunitas tubuh juga penting untuk diketahui masyarakat. Hal ini membuat peneliti tertarik untuk mengembangkan WhatsApp Bot Kita SeHatI (kabar, informasi, dan berita seputar kesehatan dan gizi). Tujuan dari penelitian ini adalah untuk mengembangkan aplikasi WhatsApp Bot sebagai media penyebaran kabar, informasi, dan berita seputar kesehatan dan gizi.

\section{METODE PENELITIAN}

Penelitian ini dilakukan pada Februari hingga Maret 2021. Semua kegiatan penelitian dan pengambilan data penelitian dilakukan secara daring. Penelitian ini mendapatkan persetujuan dari Komite Etik Penelitian Kesehatan (KEPK) Fakultas Kedokteran dan Kesehatan, Universitas Muhammadiyah Jakarta No. 049/PE/KE/FKK-UMJ/II/2021.

Perancangan WhatsApp Bot dilakukan dalam tiga tahap. Tahap pertama dilakukan untuk mengumpulkan data tentang informasi apa saja yang banyak dicari oleh masyarakat terkait kesehatan dan gizi. Data dikumpulkan menggunakan kuesioner elektronik yang disebarkan melalui WhatsApp grup. Sebanyak 139 orang subjek dipilih secara purposive. subjek merupakan Mahasiswa dari Fakultas Kedokteran dan Kesehatan, Universitas Muhammadiyah Jakarta (FKK-UMJ). Data dari pengisian kuesioner elektronik tersebut menjadi dasar informasi yang dimasukkan ke dalam WhatsApp Bot Kita SeHatI.

Tahap kedua adalah dilakukan pengembangan WhatsApp Bot. Pengembangan WhatsApp Bot dilakukan dalam beberapa tahapan seperti yang ditampilkan pada Gambar 1. Tahap ketiga setelah dilakukan pengembangan WhatsApp Bot Kita SeHatI adalah pengambilan data evaluasi. WhatsApp Bot Kita SeHatI yang sudah dikembangkan diuji coba pada 113 subjek yang merupakan mahasiswa Prodi Sarjana Gizi FKK UMJ. Setiap subjek diminta mengisi formulir evaluasi melalui kuesioner elektronik setelah mengakses WhatsApp Bot tersebut. Kuesioner berisikan 5 pertanyaan untuk evaluasi penilaian dan kemanfaatan WhatsApp Bot. Setiap pertanyaan dibuat dalam bentuk skala likert dengan penilaian 1 sampai dengan $5(1=$ Tidak Baik; 2 = Kurang Baik; 3 = Biasa Saja; 4 = Cukup Baik; 5 = Sangat Baik). Data yang diperoleh dianalisis secara deskriptif berdasarkan persentase penilaian subjek. Persentase penilaian baik oleh subjek dihitung dengan menjumlahkan persentase subjek yang memberikan penilaian dengan kriteria 4 (cukup baik) dan 5 (sangat baik).
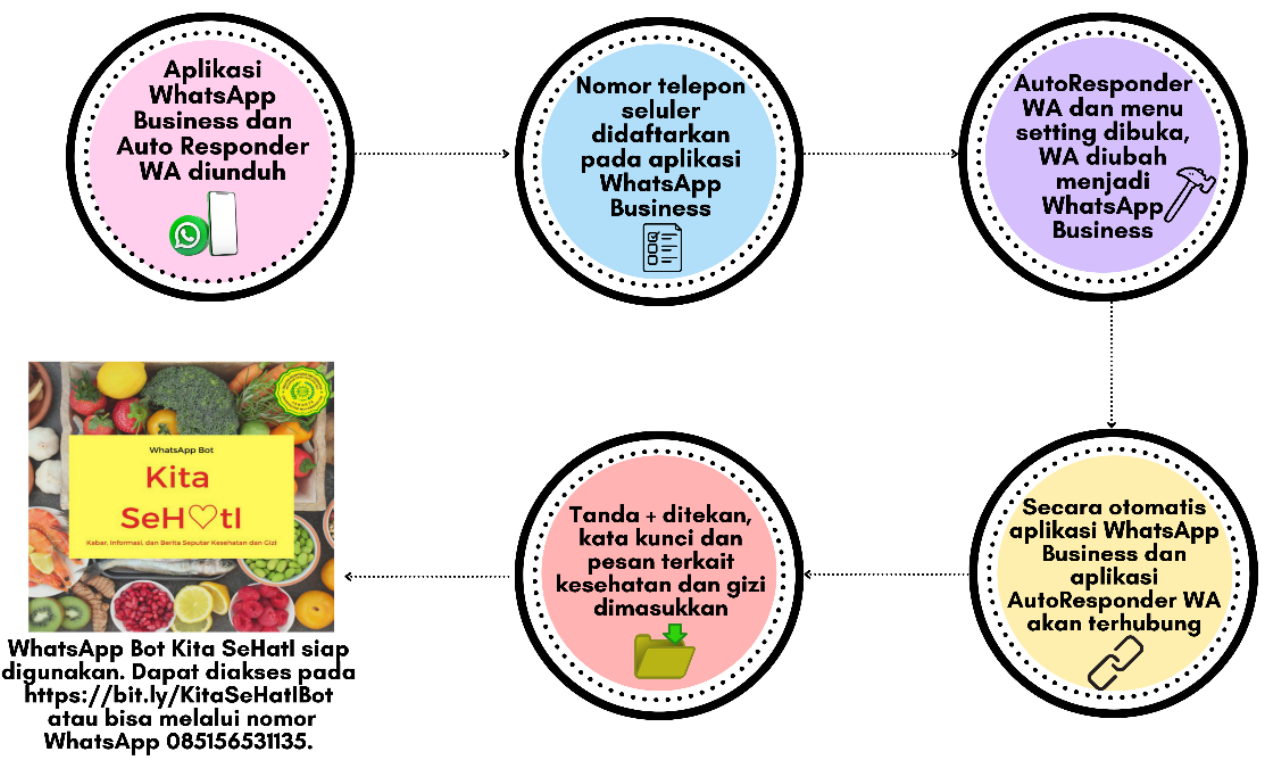

Gambar 1. Tahapan pengembangan WhatsApp Bot Kita SeHati 


\section{HASIL DAN PEMBAHASAN PENELITIAN}

Pada tahap awal dilakukan pengumpulan data tentang informasi kesehatan dan gizi apa yang banyak dicari oleh subjek serta mengetahui frekuensi penggunaan WhatsApp subjek. Gambar 2 menunjukkan persentase frekuensi penggunaan WhatsApp subjek. Sebagian besar subjek selalu menggunakan aplikasi WhatsApp $(57 \%)$.

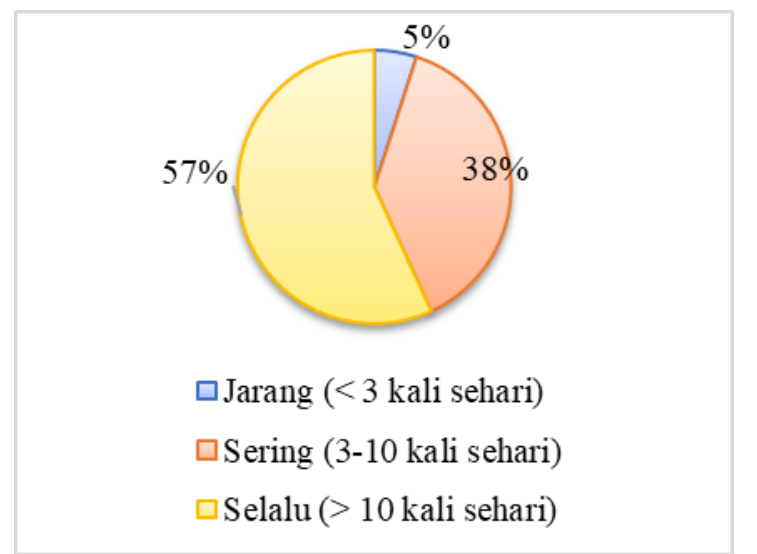

\section{Gambar 2. Sebaran frekuensi penggunaan WhatsApp subjek}

Penggunaan teknologi informasi meningkat saat ini, akibat pandemic Covid-19, termasuk di Indonesia (Zulfitria, Ansharullah and Fadhillah, 2020). Perkembangan teknologi informasi dan komunikasi perlu dimanfaatkan demi mengurangi penyebaran Covid-19. Teknologi pada smartphone semakin canggih dengan adanya aplikasi-aplikasi berbasis internet yang dapat memudahkan kegiatan manusia dalam kehidupan sehari-hari (Reflianto and Syamsuar, 2018). Salah satu yang banyak digunakan adalah WhatsApp. Potensi WhatsApp sangat besar untuk penyebaran infromasi.

WhatsApp adalah sebuah aplikasi untuk berkomunikasi dua arah yang dapat digunakan untuk mengirim pesan teks, pesan gambar, pesan video, video call, dan pesan suara. Aplikasi WhatsApp merupakan aplikasi berbasis internet yang tidak berbayar dan paling sering digunakan karena memiliki fitur-fitur seperti Galeri, Kontak, Audio, Kamera, Maps, dan Dokumen yang dapat memudahkan penggunanya (Rahartri, 2019). WhatsApp memiliki potensi yang besar untuk digunakan dalam menyebarkan informasi terkait kesehatan dan gizi (Trisnani, 2017; Hasanah, 2018).

Subjek tahap awal pada penelitian ini sebagian besar selalu menggunakan WhatsApp (57\%). Hasil ini sejalan dengan data yang diperoleh dari Kementrian Komunikasi dan Informatika Republik Indonesia tahun 2019. Sekitar 83\% dari pengguna internet adalah pengguna aplikasi WhatsApp (Kominfo, 2019). Sebagai media sosial yang paling populer, WhatsApp digunakan untuk berbagai kepentingan individu maupun sekelompok masyarakat (Trisnani, 2017).

Salah satu fitur yang dapat digunakan untuk menyebarkan informasi di WhatsApp adalah WhatsApp Bot. WhatsApp Bot merupakan fitur untuk membalas pesan secara otomatis yang telah dirancang melalui sebuah aplikasi bernama AutoResponder WA (Khan et al., 2017). Untuk dapat merespon secara otomatis, perlu memasukan kata kunci dan respon yang ingin dikirimkan. Dengan adanya fitur seperti ini diharapkan dapat memudahkan penggunanya dalam membalas pesan atau menjawab pertanyaan dari masyarakat dan juga dapat memudahkan masyarakat dalam memperoleh informasi yang dibutuhkan secara mandiri (Wijaya, Junaedy and Arfandy, 2017).

Pengembangan WhastApp Bot Kita SeHatI dilakukkan dengan mengumpulkan berbagai informasi tentang gizi dan kesehatan sesuai kategori yang banyak dicari oleh subjek pada penelitian tahap awal. Terdapat 6 kategori informasi yang diinginkan oleh subjek (Gambar 3). Ketegori tersebut terdiri dari informasi tentang olahraga; pengaturan berat badan; dampak kekurangan dan kelebihan zat gizi; asupan gizi seimbang; kandungan gizi makanan; dan makanan untuk imunitas tubuh. Informasi terkait makanan untuk imunitas tubuh paling banyak dicari oleh subjek $(37,40 \%)$. Informasi tentang olahraga berada di posisi kedua yang 
banyak dicari oleh subjek $(25,90 \%)$. subjek paling sedikit $(1,40 \%)$ mencari informasi tentang dampak kekurangan dan kelebihan zat gizi.

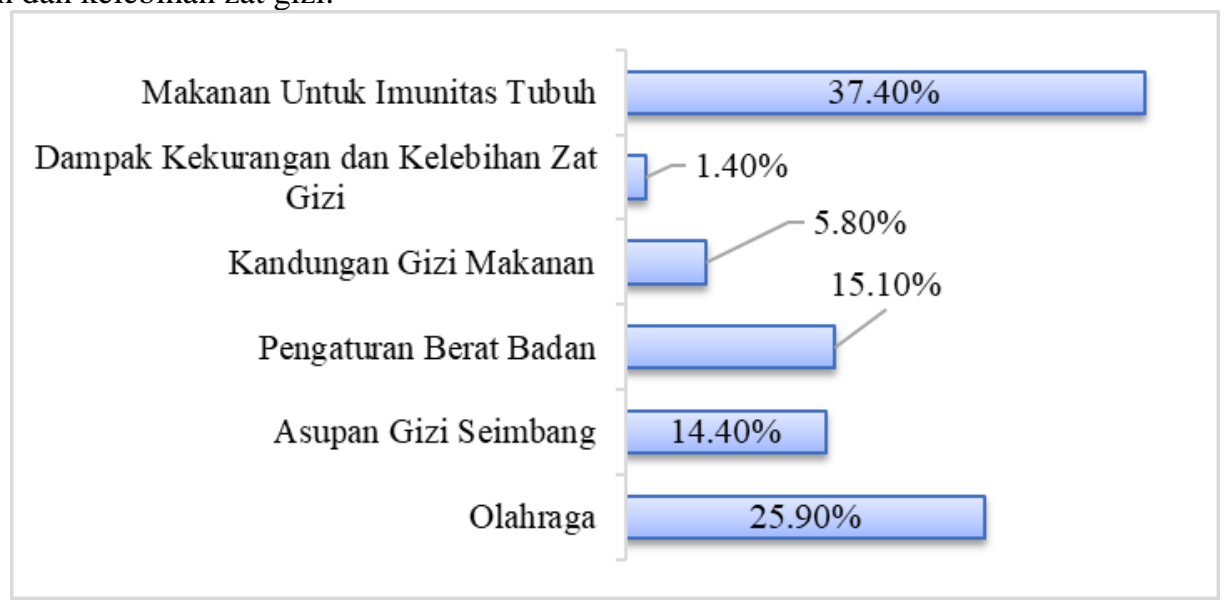

Gambar 3. Sebaran informasi yang dicari subjek

Informasi yang paling banyak dicari oleh subjek adalah tentang makanan dan minuman untuk imunitas tubuh $(37,40 \%)$. Sesuai dengan kondisi pandemi Covid-19 saat ini, terjadi perubahan kebiasaan makan masyarakat (Y1lmaz, Aslan and Unal, 2020). Informasi tersebut dicari dan sangat dibutuhkan masyarakat. Hal ini dibuktikan dengan meningkatkan konsumsi makanan dan minuman yang berdampak positif pada imunitas (Venter et al., 2020). Imunitas tubuh tergantung pada kecukupan baik kuantitas maupun kualitas gizi. Beberapa zat gizi yang berperan dalam memperkuat sistem imum antara lain protein, sayuran, vitamin, mineral dan zat fitokimia pada tanaman (Venter et al., 2020). Kampanye pemanfaatan makanan fungsional untuk meningkatkan imunitas tubuh juga meningkat (Kuswanto Vivi, 2020). Termasuk konsumsi suplemen, menjadi pilihan masyarakat yang perilaku konsumsinya meningkat saat ini (Gombart, Pierre and Maggini, 2020). Pada tahap pembuatan WhatsApp Bot Kita SeHatI, semua info terkait kategori informasi pada Gambar 3 dimasukkan. Informasi yang dimasukkan merupakan informasi ilmiah yang diambil dari jurnal penelitian dibidang kesehatan dan gizi, pedoman gizi seimbang, dan panduan kesehatan lainnya dari Kementrian Kesehatan.

Terdapat empat fitur pesan otomatis pada WhatsApp Bot yang sudah dirancang, yaitu ; memberikan sapaan kepada pengguna; memberikan pentunjuk untuk menampilkan daftar kode; memberikan daftar kode pecarian informasi; dan memberikan data informasi. Dilakukan uji coba WhatsApp Bot Kita SeHatI, sebelum diberikan pada subjek, dan diketahui bahwa semua fitur berfungsi dengan baik (Tabel 1).

Tabel 1. Fungsi Fitur WhatsApp Bot

\begin{tabular}{cc}
\hline Fitur & Keterangan \\
\hline Memberikan sapaan kepada pengguna & Berfungsi dengan baik \\
Memberikan pentunjuk untuk menampilkan daftar & Berfungsi dengan baik \\
kode & Berfungsi dengan baik \\
Memberikan daftar kode pecarian informasi & Berfungsi dengan baik \\
Memberikan data informasi &
\end{tabular}

Uji coba dilakukan pada 113 subjek. Penilaian terdiri dari beberpa aspek, yaitu aspek fungsi dari fitur yang terdapat dalam WhatsApp Bot Kita SeHatI; aspek manfaat; aspek keefektifan dan aspek penilaian secara keseluruhan. Penilaian subjek pada aspek manfaat, keefektifan, dan secara keseluruhan dapat dilihat pada Gambar 4. WhatsApp Bot Kita SeHatI dinilai bermanfaat oleh subjek (93,9\%). Sebanyak 91,8\% subjek menilai WhatsApp Bot Kita SeHatI efektif untuk mencari informasi seputar kesehatan dan gizi. Penilaian WhatsApp Bot Kita SeHatI secara keseluruhan oleh subjek sudah baik $(89,8 \%)$. 


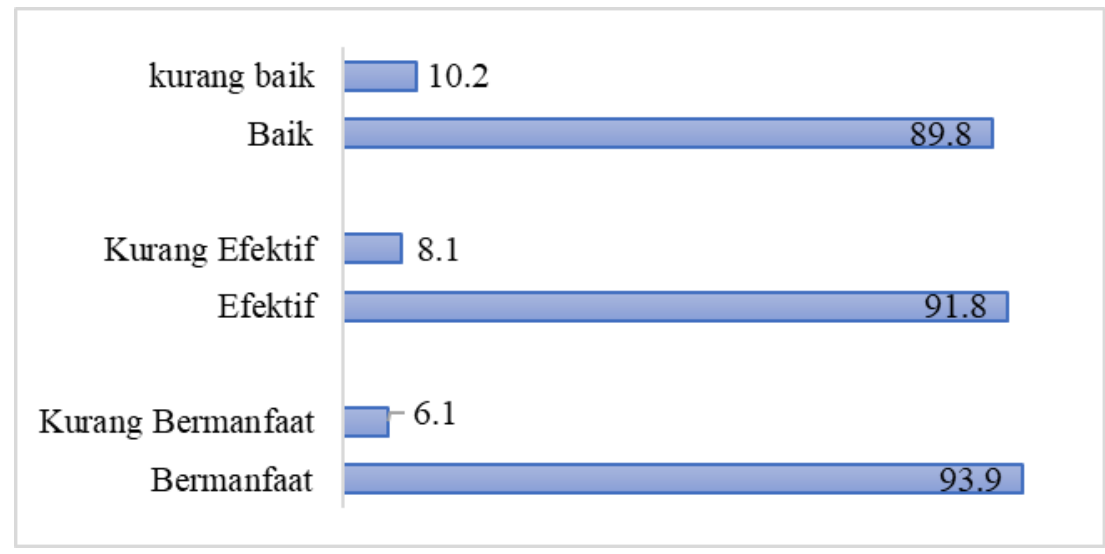

Gambar 4. Penilaian subjek pada WhatsApp Bot Kita SeHatI (\%)

Penggunaan teknologi dalam bidang kesehatan dan gizi pada era teknologi 4.0 saat ini berkembang pesat. Korea misalnya, telah mempromosikan perubahan dari layanan berorientasi perawatan medis ke paradigma yang berpusat pada $4 \mathrm{P}$, yang bersifat preventif, prediktif, personal, dan partisipatif berbasis teknologi dan dikenal dengan (Tian et al., 2019). Edukasi merupakan salah satu upaya preventif agar tidak terjadi masalah kesehatan dan gizi (Contento, 2008). Edukasi gizi untuk upaya preventif dilakukan pada semua kalangan, termasuk remaja sebagai kelompok produktif (Rusdi, Helmizar and Rahmy, 2021). Semua subjek pada penelitian ini baik pada tahap awal maupun uji coba tergolong remaja dengan kisaran usia 17-20 tahun. Kelompok ini termasuk pada generasi Z (usia 8 -23 tahun). Data Badan Pusat Statistik (BPS) tahun 2020 menunjukkan bahwa generasi ini memiliki jumlah populasi yang paling besar yaitu mencapai 27,94\% (Badan Pusat Statistik, 2021).

Penggunaan media sosial pada remaja cukup tinggi terutama Instagram dan WhatsApp, terkait dengan kebutuhan membangun kebutuhan relasi sosial dan memperoleh kesenangan (Rahardjo et al., 2020). Hal ini membuat penyebaran informasi melalui WhatsApp Bot Kita SeHatI sangat memungkinkan untuk dilakukan. Beberapa penelitian sebelumnya yang telah membuktikan keefektifan penyebaran informasi terkait kesehatan dan gizi pada remaja melalui WhatsApp (Hasanah, 2018; Zaki and Sari, 2019; Rusdi, Helmizar and Rahmy, 2021; Wardhani, Nissa and Setyaningrum, 2021). Layanan gizi berbasis teknologi bertujuan untuk pengelolaan gizi yang aktif dan meningkatkan aksesibilitas pelayanan pengelolaan gizi bagi masyarakat dan meningkatkan kesejahteraan individu.

\section{KESIMPULAN}

WhatsApp Bot Kita SeHatI dikembangkan untuk penyebaran informasi kesehatan dan gizi berbasis teknologi, mendukung perkembangan pada era teknologi 4.0. WhatsApp Bot Kita SeHatI dapat diakses pada https://bit.ly/KitaSeHatIBot atau melalui nomor WhatsApp 085156531135. WhatsApp Bot Kita SeHatI yang dikembangkan berfungsi dengan baik, dinilai bermanfaat, efektif, dan baik secara keseluruhan.

\section{SARAN}

WhatsApp Bot Kita SeHatI yang dikembangkan berfungsi dengan baik, dinilai bermanfaat, efektif, dan baik secara keseluruhan, namun masih perlu dilakukan penelitian lebih lanjut untuk menilai keefektifan WhatsApp Bot Kita SeHatI untuk peningkatan pengetahuan masyarakat tentang kesehatan dan gizi.

\section{DAFTAR PUSTAKA}

Azmi, R. (2015) 'Analisis Kesiapan Penyelenggara Jaringan Internet di Indonesia dalam Migrasi ke IPv6', Buletin Pos dan Telekomunikasi, 10(2). doi: 10.17933/bpostel.2012.100201.

Badan Pusat Statistik (2021) 'Hasil Sensus Penduduk 2020 Indonesia’, Bps.Go.Id, (27).

Bongomin, O. et al. (2020) 'Exponential Disruptive Technologies and the Required Skills of Industry 4.0', Journal of Engineering (United Kingdom). doi: 10.1155/2020/4280156.

Contento, I. R. (2008) 'Nutrition education: Linking research, theory, and practice', Asia Pacific Journal of 
Clinical Nutrition. doi: 10.1097/FCH.0b013e3182385c56.

Frank, A. G., Dalenogare, L. S. and Ayala, N. F. (2019) 'Industry 4.0 technologies: Implementation patterns in manufacturing companies', International Journal of Production Economics, 210. doi: 10.1016/j.ijpe.2019.01.004.

Gombart, A. F., Pierre, A. and Maggini, S. (2020) 'A review of micronutrients and the immune systemworking in harmony to reduce the risk of infection', Nutrients. doi: 10.3390/nu12010236.

Hasanah, N. (2018) 'Studi Kasus Potensi WhatsApp Group dalam Edukasi Gizi Seimbang Melalui Penyusunan Menu Keluarga', Berita Kedokteran Masyarakat.

Khan, M. et al. (2017) 'WhatsApp Auto Responder using Natural Language Processing and AI', International Journal of Computer Engineering \& Technology (IJCET), 8(5).

Kominfo (2019) Kominfo, WhatsApp Kenalkan Literasi Privasi Dan Keamanan Digital. Available at: https://www.kominfo.go.id/content/detail/22824/kominfo-whatsapp-kenalkan-literasi-privasi-dan-keamanandigital/0/sorotan_media.

Kuswanto Vivi, K. R. N. (2020) 'Kampanye Pemanfaatan Pangan Fungsional untuk Meningkatkan Imunitas Tubuh dalam Menghadapi Pandemi di Kabupaten Boyolali', JMM (Jurnal Masyarakat Mandiri), (Vol 4, No 5 (2020): November).

Rahardjo, W. et al. (2020) 'Adiksi Media Sosial pada Remaja Pengguna Instagram dan WhatsApp: Memahami Peran Need Fulfillment dan Social Media Engagement', Jurnal Psikologi Sosial, 18(1). doi: 10.7454/jps.2020.03.

Rahartri (2019) “"Whatsapp” Media Komunikasi Efektif Masa Kini (Studi Kasus Pada Layanan Jasa Informasi Ilmiah di Kawasan Puspiptek)', Visi Pustaka.

Reflianto and Syamsuar (2018) 'Pendidikan dan Tantangan Pembelajaran Berbasis Teknologi Informasi di Era Revolusi Industri 4.0’, Jurnal Ilmiah Teknologi Pendidikan, 6(2).

Rusdi, F. Y., Helmizar, H. and Rahmy, H. A. (2021) 'Pengaruh Edukasi Gizi Menggunakan Instagram terhadap Perubahan Perilaku Gizi Seimbang untuk Pencegahan Anemia Pada Remaja Putri di SMAN 2 Padang', Journal of Nutrition College, 10(1). doi: 10.14710/jnc.v10i1.29271.

Tian, S. et al. (2019) 'Smart healthcare: making medical care more intelligent', Journal of Global Health, 3(3). doi: 10.1016/j.glohj.2019.07.001.

Trisnani, - (2017) 'Pemanfaatan Whatsapp Sebagai Media Komunikasi Dan Kepuasan Dalam Penyampaian Pesan Dikalangan Tokoh Masyarakat', Jurnal Komunika: Jurnal Komunikasi, Media dan Informatika, 6(3). doi: 10.31504/komunika.v6i3.1227.

Venter, C. et al. (2020) 'Nutrition and the immune system: A complicated tango', Nutrients. doi: $10.3390 /$ nu12030818.

Wardhani, D. A., Nissa, C. and Setyaningrum, Y. I. (2021) 'Peningkatan Pengetahuan Remaja Putri Melalui Edukasi Gizi Menggunakan Media Whatsapp Group’, Jurnal Gizi, 10(1). doi: 10.26714/jg.10.1.2021.31-37.

We Are Social \& Hootsuite (2020) 'Indonesia Digital report 2020’, Global Digital Insights, p. 43.

Wijaya, M., Junaedy and Arfandy, H. (2017) 'Perancangan Chatbot Untuk Informasi Penerimaan Mahasiswa Baru Pada Stmik Kharisma Makassar’, Jurnal Ilmu Komputer, 1.

Y1lmaz, H. Ö., Aslan, R. and Unal, C. (2020) 'Effect of the Covid-19 pandemic on eating habits and food purchasing behaviors of university students’, Kesmas. doi: 10.21109/KESMAS.V15I3.3897. 
Yulianti, Y. et al. (2020) 'Media Usage Behavior During Covid-19 Pandemic', Diakom : Jurnal Media dan Komunikasi, 3(2). doi: 10.17933/diakom.v3i2.116.

Zaki, I. and Sari, H. P. (2019) 'Edukasi Gizi Berbasis Media Sosial Meningkatkan Pengetahuan dan Asupan Energi- Protein Remaja Putri Dengan Kurang Energi Kronik (KEK)', GIZI INDONESIA, 42(2). doi: 10.36457/gizindo.v42i2.469.

Zulfitria, Ansharullah and Fadhillah, R. (2020) 'Penggunaan Teknologi dan Internet sebagai Media Pembelajaran di Masa Pandemi Covid-19', in Prosiding Seminar Nasional Penelitian LPPM UMJ. 